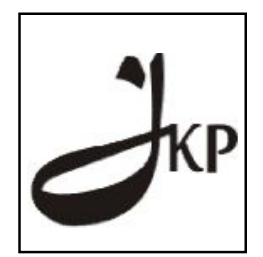

Info Artikel:

Diterima 09/02//2015

Direvisi 18/02/2015

Dipublikasikan 28/02/2015

\section{Jurnal Konseling dan Pendidikan}

ISSN Cetak: 2337-6740 - ISSN Online: 2337-6880

http://jurnal.konselingindonesia.com

Volume 3 Nomor 1, February 2015, HIm 29-34
GIICE

MULTIKARYA KONS

\title{
Hubungan Persepsi Siswa tentang Proses Peminatan dengan Aspirasi Karir Siswa
}

Ria Febriani, Yulidar Ibrahim \& Ifdil

Universitas Negeri Padang

\begin{abstract}
Penelitian ini bertujuan untuk mendeskripsikan persepsi siswa tentang proses peminatan, mendeskripsikan aspirasi karir siswa, dan menguji hubungan persepsi siswa tentang proses peminatan dengan aspirasi karir siswa. Penelitian ini berbentuk deskriptif korelasional dengan sampel 85 orang siswa. Penelitian ini menggunakan instrumen persepsi siswa tentang proses peminatan dan instrumen aspirasi karir siswa yang dikembangkan oleh Afriyadi Sofyan (2013). Dari hasil penelitian diketahui sebagian besar persepsi siswa tentang proses peminatan berada pada kategori cukup baik, namun memiliki kecenderungan baik, sebagian besar aspirasi karir siswa berada pada kategori sedang, namun memiliki kecenderungan tinggi, serta terdapat hubungan yang signifikan antara persepsi siswa tentang proses peminatan dengan aspirasi karir siswa. Perlu upaya guru BK untuk lebih meningkatkan pemberian layanan bimbingan dan konseling, agar pelaksanaan proses peminatan dapat berjalan dengan baik sehingga dapat meningkatkan persepsi siswa tentang proses peminatan dan dapat meningkatkan aspirasi karir siswa.
\end{abstract}

Keyword: Persepsi, Proses Peminatan, Aspirasi Karir

Copyright @ 2015 IICE - Multikarya Kons (Padang - Indonesia) dan IKI - Ikatan Konselor Indonesia - All Rights Reserved

Indonesian Institute for Counseling and Education (IICE) Multikarya Kons

\section{PENDAHULUAN}

Masa remaja adalah masa peralihan dari masa kanak-kanak ke masa dewasa, sehingga remaja kadangkadang masih membawa sikap kekanak-kanakan dalam bersikap maupun bersosialisasi. Sebagaimana yang diungkapkan oleh Papalia dan Olds (dalam Yudrik Jahja, 2011:220) bahwa "Masa remaja adalah masa transisi perkembangan antara masa kanak-kanak dan dewasa yang pada umumnya dimulai pada usia 12 atau 13 tahun dan berakhir pada usia akhir belasan tahun atau dua puluhan tahun”.

Remaja pada usia awal pada umumnya belum memikirkan tentang masa depan, mereka masih sibuk dengan kegiatan penyaluran hobi, minat dan berkativitas dengan teman sebaya, tetapi lambat laun remaja akan memasuki tahap dewasa yang mengharuskan remaja untuk berpikir mengenai masa depan. Masa remaja adalah masa yang penting untuk memiliki aspirasi dan cita-cita. Dengan memiliki aspirasi, siswa menjadi lebih percaya diri dan bangga akan dirinya, dan tentu saja ia sudah merencanakan masa depan dan memiliki harapan untuk meraih citacitanya, hal ini sesuai dengan yang diungkapkan oleh Anna Freud (dalam Yudrik Jahja, 2011:220).

Pemikiran mengenai masa depan, pada umumnya berorientasi pada masalah pekerjaan, ketika remaja sudah berada di bangku sekolah lanjutan atas, mereka mulai memiliki aspirasi atau cita-cita tentang karir. Sebagaimana yang diungkapkan oleh Carolyn (dalam Afriyadi Sofyan, 2013:33) bahwa aspirasi karir adalah tujuan yang ditetapkan seseorang untuk dirinya sendiri dalam suatu pekerjaan atau tugas yang memiliki arti penting bagi seseorang, dengan kata lain secara umum aspirasi karir dapat diartikan sebagai suatu harapan dalam pemilihan karir. 
Cepat atau lambat seorang remaja mulai menyadari bahwa suatu hari nanti dia harus bertanggung jawab atas kehidupannya sendiri. Saat seseorang sudah memasuki masa remaja dan saat remaja duduk di bangku SMA, aspirasi karir mulai realistis dan mulai disesuaikan dengan keadaan dan kemampuan mereka. Sebagaimana yang diungkapkan John. W. Santrock (2012:28) bahwa "Ketika di sekolah menengah, remaja sering mulai memikirkan karir berdasarkan basis yang tidak terlalu idealis. Pada usia belasan akhir dan awal dua puluhan, pengambilan keputusan karir mereka biasanya menjadi lebih serius seiring eksplorasi mereka terhadap berbagai kemungkinan karir yang ingin mereka tekuni”.

Sementara itu, menurut Pandia (dalam Afriyadi Sofyan:2013) mengemukakan aspirasi karir merupakan salah satu proses dalam perkembangan karir, dalam hal ini remaja harus mengambil keputusan akan karir yang hendak ia pilih, dan merencanakan jenjang karir yang nantinya akan ditapaki. Setelah seseorang memiliki orientasi karir, ia akan membuat rencana lebih lanjut mengenai karirnya, yang berkaitan dengan keinginan untuk berprestasi dan mencapai posisi tinggi dalam pekerjaan, inilah yang merupakan aspirasi karir.

Salah satu faktor yang mempengaruhi aspirasi karir siswa ialah jurusan atau program studi yang dipilihnya. Sebagaimana yang dikemukakan oleh Nauta (dalam Afriyadi Sofyan, 2013:51) yang mengemukakan tentang pengaruh jurusan atau program studi tertentu terhadap aspirasi karir yang ia miliki. Dalam penelitiannya ia menyatakan "The findings from this study support basic tenets of social-cognitive theory as applied to womans higher level career aspirations in math, science, and engineering". Nauta mengemukakan bahwa siswa dengan jurusan tertentu dan dengan karakteristik yang ada memiliki kecendrungan kepercayaan diri dalam aspirasi karirnya yag berbeda. Dengan demikian, dapat disimpulkan bahwa jurusan (program studi) yang diambil siswa disekolah memiliki peluang dalam menentukan tingkat aspirasi karir siswa.

Pada tahun 2013 sudah diberlakukannya kurikulum 2013 untuk SMA. Penjurusan atau program studi sudah berganti namanya menjadi peminatan. Dalam konstruk dan isinya kurikulum tahun 2013 mementingkan terselenggaranya proses pembelajaran secara interaktif, inspiratif, menyenangkan, menantang, memotivasi siswa untuk berpartisipasi aktif serta memberi ruang yang cukup bagi prakarsa, kreativitas dan kemandirian sesuai dengan bakat, minat, dan perkembangan siswa (Kementrian Pendidikan Dan Kebudayaan, 2013).

Fokus utama dalam kerangka kurikulum 2013 yakni adanya program peminatan yang dilaksanakan oleh guru BK/Konselor. Peminatan dalam kurikulum 2013 ini mencakup kelompok mata pelajaran wajib, kelompok mata pelajaran peminatan serta kelompok mata pelajaran pendalaman dan lintas minat untuk siswa SMA/MA yang merupakan bagian yang tak terpisahkan dan terintegrasi dalam program pelayanan bimbingan dan konseling pada satuan pendidikan, khususnya jenjang pendidikan menengah. Artinya, program pelayanan bimbingan dan konseling pada satuan pendidikan harus memuat pelayanan peminatan baik kelompok mata pelajaran maupun lintas minat mata pelajaran. Peminatan memberikan kesempatan yang cukup luas bagi siswa untuk menempatkan diri pada jalur yang lebih tepat dalam rangka penyelesaian studi secara terarah, sukses, dan jelas dalam arah pendidikan selanjutnya.

Dengan adanya program peminatan ini, siswa mampu berkembang dengan terarah dan terfokus pada terwujudnya suatu kondisi yang mempertimbangkan kemampuan dasar, bakat, minat, dan kecendrungan pribadi individu. Dengan adanya peminatan, siswa memiliki cita-cita atau aspirasi tentang karir di masa depan. Sebagaimana yang diungkapkan oleh Kemendikbud (2013) bahwa "Peminatan individu atau siswa pertama-tama terarah dan terfokus pada peminatan studi dan karir atau pekerjaan".

Program peminatan yang telah dilaksanakan di sekolah tentunya menimbulkan berbagai persepsi dari siswa. Menurut Chaplin, J.P. (2011:358) persepsi adalah proses mengetahui atau mengenali objek dan kejadian objektif dengan bantuan indera kemudian memberikan makna terhadap objek yang dikenali tersebut. Baik buruknya persepsi siswa tentang proses peminatan akan mempengaruhi kecendrungan siswa untuk menentukan cita-citanya atau aspirasi karir.

Bimbingan dan konseling sebagai salah satu wilayah layanan pendidikan di sekolah memiliki peran strategis untuk membantu siswa agar dapat menavigasi perjalanan hidupnya melalui pengambilan keputusan dalam rangka memilih, meraih dan mempertahankan karirnya guna mewujudkan kehidupan yang produktif dan sejahtera, serta untuk menjadi warga masyarakat yang peduli kemaslahatan umum.

Fenomena yang terjadi di lapangan berdasarkan wawancara peneliti dengan guru BK SMA Negeri 10 Padang pada tanggal 10 Februari 2014, beliau menyatakan bahwa beberapa siswa masih belum mengetahui kemana arah karirnya nanti. selain itu, ada siswa yang memasuki program peminatan MIA karena dipaksa oleh orangtua, padahal ia ingin sekali memasuki program peminatan IIS. Dan orangtua memaksakan kehendak untuk 
menyuruh anaknya menjadi apa yang diinginkan orangtua, seperti harus menjadi dokter sehingga harus mengambil program peminatan MIA.

Kemudian beliau juga menyatakan proses peminatan yang dilaksanakan di SMA Negeri 10 Padang ini khususnya untuk kelas $\mathrm{X}$ belum optimal seperti yang diharapkan. Sehingga hal ini akan akan timbul berbagai pandangan dari siswa itu sendiri terhadap pelaksanaan proses peminatan.

Selanjutnya hasil wawancara dengan siswa kelas X SMA Negeri 10 Padang pada tanggal 12 Februari melalui 3 orang siswa. Kesimpulan dari wawancara tersebut siswa mengungkapkan bahwa penilaian mereka terhadap proses peminatan belum begitu baik. Siswa menyatakan proses pembelajaran pada program peminatan ini tidak berbeda dengan proses pembelajaran di tingkat pendidikan sebelumnya. Selain itu siswa juga mengungkapkan dengan adanya program peminatan ini masih belum memberikan kontribusi untuk mengetahui cita-cita mereka nantinya.

Kemudian peneliti melanjutkan wawancara dengan 2 orang siswa pada tanggal 19 Februari 2014. Hasil wawancara tersebut juga didapatkan informasi tentang persepsi siswa tentang pelaksanaan peminatan, yaitu siswa menyampaikan bahwa proses pembelajaran di kurikulum 2013 ini akan mempengaruhi kecendrungan cita-cita nantinya. Namun, siswa masih meragukan apakah dengan proses peminatan yang telah dilalui bisa membantu mereka dalam mewujudkan cita-cita mereka.

Berdasarkan penelitian Elmirawati (2013) di SMAN 1 Singingi Hilir dapat disimpulkan bahwa tingkat aspirasi (cita-cita) siswa tergolong sedang. Untuk aspirasi pekerjaan, sebagian siswa menganggap cukup penting pendidikan di masa akan datang. Siswa lebih banyak menginginkan pekerjaan semi profesional, dan mengganggap pekerjaan yang dipilihnya cukup penting.

Sesuai dengan data yang diperoleh penulis dari guru BK di SMA Negeri 10 Padang mengenai siswa IPA yang memasuki jurusan IPS di perguruan tinggi sebelum diaksanakannya program peminatan di sekolah tersebut adalah sebagai berikut:

Tabel 1. Jumlah Siswa dari Jurusan IPA yang Memasuki Jurusan IPS

\begin{tabular}{|c|c|c|c|c|}
\hline No. & Tahun Ajaran & $\begin{array}{c}\text { f } \\
\text { Siswa }\end{array}$ & $\begin{array}{c}\text { f } \\
\text { Siswa yang tamat }\end{array}$ & \% \\
\hline 1. & $2010-2011$ & 36 & 167 & 21,6 \\
\hline 2. & $2011-2012$ & 45 & 145 & 31,03 \\
\hline 3. & $2012-2013$ & 32 & 194 & 19 \\
\hline
\end{tabular}

Bertitik tolak dari fenomena tersebut peneliti merasa tertarik untuk mengkaji persoalan proses peminatan dalam hal ini peneliti mencoba memberi judul penelitian yaitu "Hubungan persepsi siswa tentang proses peminatan dengan aspirasi karir siswa", apakah terdapat hubungan persepsi siswa tentang proses peminatan dengan aspirasi karir siswa?.

Tujuan penilitian adalah (1) mendeskripsikan persepsi siswa tentang proses peminatan, (2) mendeskripsikan aspirasi karir siswa, (3) menguji hubungan persepsi siswa tentang proses peminatan dengan aspirasi karir siswa.

\section{METODOLOGI PENELITIAN}

Penelitian ini merupakan penelitian deskriptif korelasional, dengan sampel 85 siswa. Instrumen yang digunakan untuk mengumpulkan data dalam penelitian ini adalah instrumen persepsi siswa tentang proses peminatan dan instrumen aspirasi karir siswa yang dikembangkan oleh Afriyadi Sofyan (2013). Menjawab pertanyaan penelitian 1 dan 2 data hasil penelitian dianalisis dengan menggunakan teknik analisis statistik deskriptif dan menjawab pertanyaan 3 dianalisis dengan analisis statistik inferensial dengan menggunakan Pearson Correlation dengan bantuan program komputer 
HASIL

Berdasarkan hasil pengolahan data, maka hasil penelitian ini dapat digambarkan sebagai berikut:

Tabel 2. Persepsi Siswa Tentang Proses Peminatan di SMA Negeri 10 Padang

\begin{tabular}{|c|c|c|}
\hline Kriteria & F & \% \\
\hline Sangat Baik & 7 & 8 \\
\hline Baik & 19 & 22 \\
\hline Cukup Baik & 33 & 39 \\
\hline Kurang Baik & 22 & 26 \\
\hline Tidak Baik & 4 & 5 \\
\hline
\end{tabular}

Berdasarkan Tabel 2 terungkap 8\% persepsi siswa tentang proses peminatan berada pada kategori sangat baik, $22 \%$ berada pada kategori baik, 39\% berada pada kategori cukup baik, $26 \%$ berada pada kategori kurang baik, dan 5\% berada pada kategori tidak baik. Maka dapat disimpulkan bahwa sebagian besar persepsi siswa tentang proses peminatan berada pada kategori cukup baik dengan persentase 39\%, namun dalam hal ini kecendrungan persepsi siswa tentang proses peminatan yaitu baik dengan persentase $31 \%$.

Tabel 3. Aspirasi Karir Siswa SMA Negeri 10 Padang

\begin{tabular}{|l|c|c|}
\hline \multicolumn{1}{|c|}{ Kriteria } & F & \% \\
\hline Sangat Tinggi & 6 & 7 \\
\hline Tinggi & 24 & 28 \\
\hline Sedang & 33 & 39 \\
\hline Rendah & 14 & 16 \\
\hline Sangat Rendah & 8 & 10 \\
\hline
\end{tabular}

Berdasarkan Tabel 3 dapat diketahui bahwa 7\% aspirasi karir siswa berada pada kategori sangat tinggi, 28\% berada pada kategori tinggi, 39\% berada pada kategori sedang, $16 \%$ berada pada kategori rendah, dan $10 \%$ berada pada kategori sangat rendah. Maka dapat disimpulkan bahwa sebagian besar aspirasi karir siswa berada pada kategori sedang dengan persentase 39\%, namun dalam hal ini kecendrungan aspirasi karir siswa yaitu tinggi dengan persentase $35 \%$.

Kemudian, untuk melihat hubungan antara persepsi siswa tentang proses peminatan dengan aspirasi karir siswa digunakan analisis Pearson Correlation dengan pengolahan data menggunakan bantuan komputer melalui program SPSS, hasil uji hipotesis dapat dilihat pada tabel berikut ini:

Tabel 4. Hubungan Persepsi Siswa Tentang Proses Peminatan dengan Aspirasi Karir Siswa SMA Negeri 10 Padang

\begin{tabular}{|c|c|c|c|}
\hline & & $\begin{array}{l}\text { Persepsi_Siswa_tenta } \\
\text { ng_Proses_Peminatan }\end{array}$ & Aspirasi_Karir \\
\hline \multirow{3}{*}{$\begin{array}{l}\text { Persepsi } \\
\text { Siswa tentang } \\
\text { Proses } \\
\text { Peminatan }\end{array}$} & Correlation & 1 & $0,336^{* *}$ \\
\hline & Sig & & ,002 \\
\hline & $\mathrm{N}$ & 85 & 85 \\
\hline \multirow[t]{3}{*}{ Aspirasi Karir } & Correlation & 1 & $0,336^{* *}$ \\
\hline & Sig & &, 002 \\
\hline & $\mathrm{N}$ & 85 & 85 \\
\hline
\end{tabular}

**Correlation is significant at the 0.01 level ( 2 tailed). 
Berdasarkan tabel 16 diketahui bahwa besarnya korelasi antara persepsi siswa tentang proses peminatan dengan aspirasi karir siswa di SMA Negeri 10 Padang sebesar 0,336 dengan signifikan 0,002. Jika dibandingkan dengan probabilitasnya 0,01 maka $0,002<0,01$. Oleh karena itu hipotesis kerja (Ha) yang diajukan dalam penelitian adalah terdapat hubungan yang signifikan antara persepsi siswa tentang proses peminatan dengan aspirasi karir siswa SMA Negeri 10 Padang dapat diterima. Sehingga dapat ditafsirkan bahwa terdapat hubungan yang signifikan antara persepsi siswa tentang proses peminatan dengan aspirasi karir siswa SMA Negeri 10 Padang.

\section{PEMBAHASAN}

Pembahasan ini dilakukan berdasarkan pertanyaan penelitian yaitu bagaimana kondisis persepsi siswa tentang proses peminatan, bagaimana tingkat aspirasi karir siswa, dan apakah terdapat hubungan persepsi siswa tentang proses peminatan dengan aspirasi karir siswa.

\section{A. Persepsi Siswa Tentang Proses Peminatan di SMA Negeri 10 Padang}

Berdasarkan hasil penelitian persepsi siswa tentang proses peminatan diperoleh data bahwa sebagian besar persepsi siswa tentang proses peminatan berada pada kategori cukup baik dengan persesntase $39 \%$, namun dalam hal ini kecenderungan persepsi siswa tentang proses peminatan yaitu baik dengan persentase $31 \%$. Hal ini menunjukkan bahwa siswa telah memiliki persepsi yang cukup baik serta memiliki kecenderungan baik tentang proses peminatan yang dilaksanakan di SMA Negeri 10 ini.

Pada dasarnya persepsi atau pemahaman, penafsiran dan penilaian seseorang terhadap suatu objek akan mempengaruhinya untuk melakukan respon baik itu positif atau negatif. Jadi, persepsi siswa tentang proses peminatan akan mempengaruhi siswa dalam mengikuti proses pelaksanaan peminatan tersebut. Sebagaimana yang tertuang dalam Kementrian Pendidikan dan Kebudayaan (2013) yang menyatakan bahwa Program peminatan merupakan program pendidikan yang menunjang pengembangan dan perwujudan peminatan siswa secara optimal dengan memperhatikan dan memanfaatkan sepenuhnya segenap unsur-unsurnya, baik yang secara inheren ada pada diri pribadi siswa, maupun segenap kondisi positif yang ada di lingkungan siswa (lingkungan keluarga, kelompok, masyarakat dan budaya), dan segenap fasilitas prasarana dan sarana kependidikan yang ada.

Meskipun sebagian besar persepsi siswa tentang proses peminatan berada pada kategori cukup baik dengan persesntase $39 \%$, namun dalam hal ini kecenderungan persepsi siswa tentang proses peminatan yaitu baik dengan persentase $31 \%$. Hal ini menunjukkan bahwa siswa telah memiliki persepsi yang baik tentang proses peminatan yang dilaksanakan di SMA Negeri 10 ini.

\section{B. Aspirasi Karir Siswa SMA Negeri 10 Padang}

Berdasarkan hasil penelitian menunjukkan bahwa sebagian besar aspirasi karir siswa berada pada kategori sedang dengan persentase 39\%, namun dalam hal ini kecenderungan aspirasi karir siswa yaitu tinggi dengan persentase $35 \%$. Hal ini menunjukkan bahwa siswa telah memiliki aspirasi karir yang tinggi. Aspirasi karir adalah keinginan atau cita-cita dari seseorang untuk mendapatkan kemajuan dalam bidang pekerjaan dan jabatannya. Nauta, Epperson dan Kahn (dalam A. Smulders, 2007:11) mendefinisikan aspirasi karir sebagai sejauh mana orang bercita-cita untuk posisi kepemimpinan atau lanjutan dalam pilihan pekerjaan mereka.

\section{Hubungan Persepsi Siswa Tentang Proses Peminatan Dengan Aspirasi Karir Siswa}

Penelitian ini dilakukan untuk mengetahui ada tidaknya hubungan antara persepsi siswa tentang proses peminatan dengan aspirasi karir siswa di SMA Negeri 10 Padang. Setelah melakukan analisis uji korelasi dengan menggunakan program komputer Statistic Product and Service Solution (SPSS) for Windows release 20,0. Atau menggunakan rumus Pearson Correlation. Berdasarkan tabel 16 diketahui bahwa besarnya korelasi antara persepsi siswa tentang proses peminatan dengan aspirasi karir siswa di SMA Negeri 10 Padang sebesar 0,336 dengan signifikan 0,002. Jika dibandingkan dengan probabilitasnya 0,01 maka $0,002<0,01$. Oleh karena itu hipotesis kerja $(\mathrm{Ha})$ yang diajukan dalam penelitian adalah terdapat hubungan yang signifikan antara persepsi siswa tentang proses peminatan dengan aspirasi karir siswa SMA Negeri 10 Padang dapat diterima. Sehingga dapat ditafsirkan bahwa terdapat hubungan yang signifikan antara persepsi siswa tentang proses peminatan dengan aspirasi karir siswa SMA Negeri 10 Padang.

Hasil temuan ini menguatkan pendapat Nauta (dalam Afriyadi Sofyan, 2013:51) yang mengemukakan tentang pengaruh jurusan atau program studi tertentu terhadap aspirasi karir yang ia miliki. Dalam penelitiannya ia menyatakan "The findings from this study support basic tenets of social-cognitive theory as applied to womans 
higher level career aspirations in math, science, and engineering". Nauta mengemukakan bahwa siswa dengan jurusan tertentu dan dengan karakteristik yang ada memiliki kecendrungan kepercayaan diri dalam aspirasi karirnya yag berbeda. Dengan demikian, dapat disimpulkan bahwa jurusan (program studi) yang diambil siswa disekolah memiliki peluang dalam menentukan tingkat aspirasi karir siswa.

Menurut Danziger dan Eden (dalam dalam A. Smulders, 2007:10) dijelaskan bahwa aspirasi karir adalah membina seseorang untuk mewujudkan tujuan karir yang diinginkan. Mereka juga berpendapat bahwa aspirasi karir yang terkait dengan harapan karir seseorang dan persepsi individu adalah gagasan dan penilaian, yang merupakan produk yang terdiri dari proses pengorganisasian mental, pengintegrasian, dan pengakuan terhadap kenyataan yang ada.

\section{KESIMPULAN DAN SARAN}

\section{A. Kesimpulan}

Berdasarkan penelitian yang telah dilakukan dapat disimpulkan bahwa sebagian besar persepsi siswa tentang proses peminatan berada pada kategori cukup baik, namun kecenderungan persepsi siswa tentang proses peminatan yaitu baik. Sebagian besar aspirasi karir siswa berada pada kategori sedang, namun kecenderungan aspirasi karir siswa yaitu tinggi. Terdapat hubungan yang signifikan antara persepsi siswa tentang proses peminatan dengan aspirasi karir siswa.

\section{B. Saran}

Berdasarkan simpulan dari hasil penelitian, maka saran yang diberikan kepada seluruh personil sekolah yakni guru BK, kepala sekolah, guru mata pelajaran, dan siswa untuk lebih meningkatkan pelaksanaan proses peminatan di sekolah agar persepsi siswa tentang proses peminatan dapat ditingkatkan dan dapat meningkatkan aspirasi karir siswa.

\section{DAFTAR PUSTAKA}

Afriyadi Sofyan. 2013. Tingkat Aspirasi Karir Siswa Ditinjau Dari Jenis Kelamin, Jurusan Dan Daerah Tempat Tinggal (Peneltian di SMAN 1 Megang Sakti dan SMAN 1 Lubuklinggau). Padang: Tesis. Program Pascasarjana Universitas Negeri Padang. Tidak diterbitkan.

Elmirawati. 2013. Hubungan Antara Aspirasi Siswa dan Dukungan Orangtua Dengan Motivasi Belajar Serta Implikasinya Terhadap Bimbingan Konseling. Padang: Tesis Fakultas Ilmu Pendidikan Universitas Negeri Padang. Tidak diterbitkan.

Chaplin, J.P. 2011. Kamus Lengkap Psikologi (Alih Bahasa Oleh Kartini Kartono). Jakarta: Rajawali Pers

John W. Santrock. 2012. Life-Span Development Perkembangan Masa Hidup Edisi Ketigabelas Jilid 2. Jakarta: Erlangga

Kemendikbud. 2013. Pedoman Peminatan Peserta Didik. Jakara: Badan Pengembangan SDM Pendidikan Dan Kebudayaan Dan Penjaminan Mutu Pendidikan, Kementrian Pendidikan Dan Kebudayaan

Smulders, Annete. 2009. Student Career Aspirations: The Effect Of Year Of Study, Gender And Personality Traits. University of Maastricht

Yudrik Jahja. 2011. Psikologi Perkembangan. Jakarta: Kencana 